\title{
Vector-borne Zoonotic Diseases in Turkey: Rising Threats on Public Health
}

\author{
Türkiye'de Vektörlerle Bulaşan Zoonotik Hastalıklar: Halk Sağlığına \\ YönelikArtan Tehditler
}

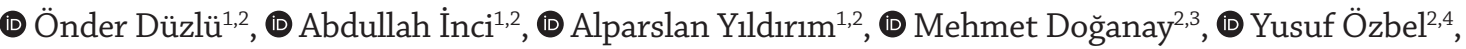 \\ (1) Serap Aksoy ${ }^{5}$
}

${ }^{1}$ Erciyes University, Faculty of Veterinary Medicine, Department of Parasitology, Kayseri, Turkey

${ }^{2}$ Erciyes University, Vectors and Vector-Borne Diseases Implementation and Research Centre, Kayseri, Turkey

${ }^{3}$ Erciyes University, Faculty of Medicine, Department of Infection Diseases and Clinical Microbiology, Kayseri, Turkey

${ }^{4}$ Ege University, Faculty of Medicine, Department of Parasitology, İzmir, Turkey

${ }^{5}$ Yale School of Public Health, Department of Epidemiology of Microbial Diseases, USA

Cite this article as: Düzlü Ö, İnci A, Yıldırım A, Doğanay M, Özbel Y, Aksoy S. Vector-borne Zoonotic Diseases in Turkey:

Rising Threats on Public Health. Turkiye Parazitol Derg 2020;44(3):168-75.

\begin{abstract}
Vector-borne zoonotic diseases (VBZDs) are a major problem for public health and animal welfare all over the world. In recent years, there has been an alarming increase in VBZDs, mainly caused by new or re-emerging arboviruses, bacteria and parasites. The World Health Organization enumerated 10 threats to global health for 2019, notably emphasizing climate change and emerging pathogens as growing priorities. It is important to review potential threats and develop new control programs for rising threats against human health and safety. Changes in host and vector population diversity and density may affect pathogen transmission patterns and influence VBZD emergence processes. In addition to environmental and climate-related changes, human and animal migratory patterns pose future threats. The geographic location and habitat features of Turkey support the establishment of many arthropod species as vectors of various diseases. To date, a total of 107 zoonotic infections have been reported originating from Turkey. Arthropods transmit 19 of 107 such infections, including 2 mosquito-borne, 9 tick-borne, 1 sandfly-borne, 3 flea-borne, 1 simuliid-borne, 1 mite-borne and 2 fly-borne diseases. In this review, we focus on the present status of knowledge on VBZDs as a rising threat to public health in Turkey to provide a foundation for future control efforts.
\end{abstract}

Keywords: Vectors, zoonoses, vector-borne diseases, Turkey

öz

Vektörlerle bulaşan zoonotik hastalıklar (VBZD), tüm dünyada halk sağlığı ve hayvan refahı açısından önemli bir sorundur. Son yıllarda, yeni veya yeniden ortaya çıkan arbovirüs, bakteri ve parazitlerin neden olduğu VBZD olgularında endişe verici bir artış görülmektedir. Dünya Sağlık Örgütü, özellikle iklim değişikliğini ve emerging patojenleri öne çıkararak, 2019 yılında küresel sağlık için 10 farklı tehdit belirlemiştir. Sağlık ve güvenlik açısından, artan tehditlere karşı potansiyel tehditleri gözden geçirmek ve yeni kontrol programları geliştirmek oldukça önemlidir. Konak ve vektör popülasyon çeşitliliği ve yoğunluğundaki değişiklikler, patojenlerin bulaşma dinamiklerini ve VBZD'nin oluşum süreçlerini etkileyebilmektedir. Çevresel ve iklim değişikliklerinin yanı sıra, insan ve hayvan hareketleri de gelecek için tehdit oluşturmaktadır. Türkiye, coğrafi konumu ve habitat özelliği nedeniyle çeşitli hastalıkların vektörlüğünü yapan birçok artropodun barındığı bir ülkedir. Bugüne kadar, Türkiye'den toplam 107 zoonotik enfeksiyon rapor edilmiştir. Bu 107 enfeksiyonun 19'unu (ikisini sivrisinekler, dokuzunu keneler, birini tatarcıklar, üçünü pireler, birini simuliidler, birini akarlar, ikisini sinekler) artropodlar nakletmektedir. Bu derlemede, gelecekteki kontrol mücadelelerine temel oluşturmak amacıyla, Türkiye'de halk sağllğı için artan bir tehdit olan VBZD'lerin güncel durumu hakkında bilgi verilmiştir. Anahtar Kelimeler: Vektörler, zoonozlar, vektörlerle bulaşan hastalıklar, Türkiye 


\section{INTRODUCTION}

The geographic location of Turkey plays an important role as a natural bridge between Europe and Caucasus, Asia, Africa. Besides its economic significance, this geographic location also impacts the epidemiology of several zoonotic diseases for public health of regional significance $(1,2)$.

Zoonotic diseases have gained increasing importance for public health with many of the most important ones involving wildlife and arthropod vectors, collectively called vector-borne and zoonotic diseases (VBZD) (3). VBZDs are caused by multifarious viruses, bacteria and parasites (4), that are transmitted by blood feeding insects, ticks as well as snails. Environmental changes (urbanization, etc), extreme natural events (tropical cyclones, flood, earthquakes, tsunami, etc), human factors (immigration and travels, international trades, etc), and climate change are among the factors favoring the potential emergence of new VBZDs or reemergence of old foes (5). Changes in global climate and habitat suitability influence the expansion and distribution of vector arthropods and enable otherwise geographically restricted pathogens to be transmitted to susceptible animals and humans living in new territories (6). The reproductive biology, behavioral activities, and population dynamics of the arthropod vectors, as well as development of pathogens in arthropod vectors are also affected by varying climatic factors, such as humidity, temperature, soil and vegetation status, among others. It is important to document and predict the potential effects of these changes on the interactions among pathogens and their hosts, including wild and domestic animals, and humans. Collectively, better understanding of these drivers and their effects on disease transmission are important for the development of appeasement strategies and will enable timely and effective responses for VBDZ control $(6,7)$.

In Turkey, a total of 107 zoonotic infections (37 bacterial, 13 fungal, 29 viral, 28 parasitic) have been reported to date (Table 1). Among these, 19 are transmitted by arthropod vectors (Figure 1) $(2,8)$. Furthermore, 21 of these zoonotic diseases are considered high priority in Europe and listed by the experts of Discontools (2).

Here, we review the current knowledge on the most important VBZDs for public health safety in Turkey (Table 1). This knowledge can provide a foundation for future studies that are aimed to design new preventive and control strategies that can benefit not only Turkey but also the larger region.

\section{Mosquito-borne Zoonotic Diseases}

Arguably, mosquitoes are involved in the transmission of the most devastating diseases to humans and animals. Among the mosquito transmitted zoonotic diseases, Dirofilariasis and West Nile virus (WNV) are of significance in Turkey. The species Dirofilaria immitis affects pulmonary arteries of dogs and cats and is the most prevalent parasite in human infections. Canine dirofilariosis is widespread in Turkey with prevalence rates reported as $0.2-30.0 \%$ (9-11). Molecular methods have determined Aedes vexans within the Culicidae family to be the main vector species responsible for D. immitis transmission in Kayseri region of Turkey (12). Some human cases were also reported as orbital dirofilariasis (13-15), premasseteric (16) and foot nodules (17).

WNV is a flavivirus (family Flaviviridae), affecting birds, humans and horses, and is maintained in a mosquito-bird transmission cycle, with humans and horses considered dead-end hosts. Although most cases are asymptomatic, nearly $20 \%$ of infected humans become symptomatic (18). The first WNV outbreak in Turkey was reported as in 2010 with 47 cases diagnosed between 2010-2011, and international notification was mandated for the first time (19). WNV cases have been reported from several regions of the country with Culex pipiens mosquitoes being the primary vector responsible for transmission (2). The serologic prevalence rates were reported as $1-16 \%$ in humans (20) and $1-38 \%$ in domestic animals $(21,22)$. Recent molecular epidemiological studies have detected WNV in horses in Central Anatolia region (23).

\section{Tick-borne Zoonotic Diseases}

In Turkey, ticks are prominent vectors involved in the transmission of VBZDs, including Babesiosis, Anaplasmosis, Ehrlichiosis, Crimean-Congo hemorrhagic fever (CCHF), Louping-ill, Lyme borreliosis (LB), Tularemia, Q-fever, and Dermatophilosis.

Babesiosis is the first described disease involving ixodid ticks in the Ixodes genus in Turkey. The infection is highly prevalent in domestic animals throughout the country and has a major significance for cattle industry, while no clinical cases have been reported in humans to date (8). However, serological analyses in humans have indicated seropositivity rates for Babesia microti, B. divergens, and B. bovis as $6.23 \%$ (24), $8 \%$ (25), and $18 \%$ (26), respectively.

Anaplasmosis is caused by obligate and intracytoplasmic bacteria in the order Rickettsiales. Anaplasma phagocytophilum is responsible for human granulocytic anaplasmosis and has been reported from farm animals (27) and humans (28) in Turkey. Furthermore, A. phagocytophilum was detected in Ixodes ricinus ticks obtained from humans (29). In addition, several bovine anaplasmosis outbreaks were reported from cattle (30-32), and an infection caused by A. platys was determined in a dog (33).

Ehrlichia chaffeensis is the most important species for human monocytotropic ehrlichiosis (HME), while E. canis is the major agent causing canine monocytotropic ehrlichiosis (CME), all being transmitted by ixodid ticks. Globally, HME cases have been on the rise reaching 3.4 per million in 2010 (34). In Turkey, studies on $\mathrm{CME}$ are limited to a few reports that describe seropositivity (35), clinical cases and treatment (36), and molecular prevalence $(37,38)$, while there are no reports about HME. Based on serological studies reported from different provinces of Turkey, E. canis prevalence rates range from $4.8 \%$ to $41.5 \%$, while no $E$. ewingii or E. chaffeensis cases have been recorded. The first clinical canine ehrlichiosis case was reported in Aydin province (33) and a molecular study from Kayseri region reported $E$. canis prevalence to be $15 \%$ (37).

CCHF, caused by a Nairovirus in Bunyaviridae, is a reemerging tick-borne infection transmitted by either ixodid tick species (mainly by Hyalomma marginatum), or by direct contact with blood or tissues belonging to viremic patients or animals. CCHF has caused outbreaks especially in Turkey, Russia, Iran, Pakistan, and Afghanistan in the past two decades (39). In Turkey, CCHF first emerged in Tokat province of the Black Sea Region in 2002 and has subsequently spread throughout the country $(40,41)$. An increase in CCHF cases was observed especially in 2008 and 2009. Since 2002, a total of 9,787 cases have been reported until 2015 $(2,8,42)$ with 469 cases resulting in death in humans (4.79\%). Louping ill virus (LIV) is another tick-borne pathogen (genus 
Table 1. Vector-borne zoonotic diseases, causative agents, hosts, and vectors in Turkey

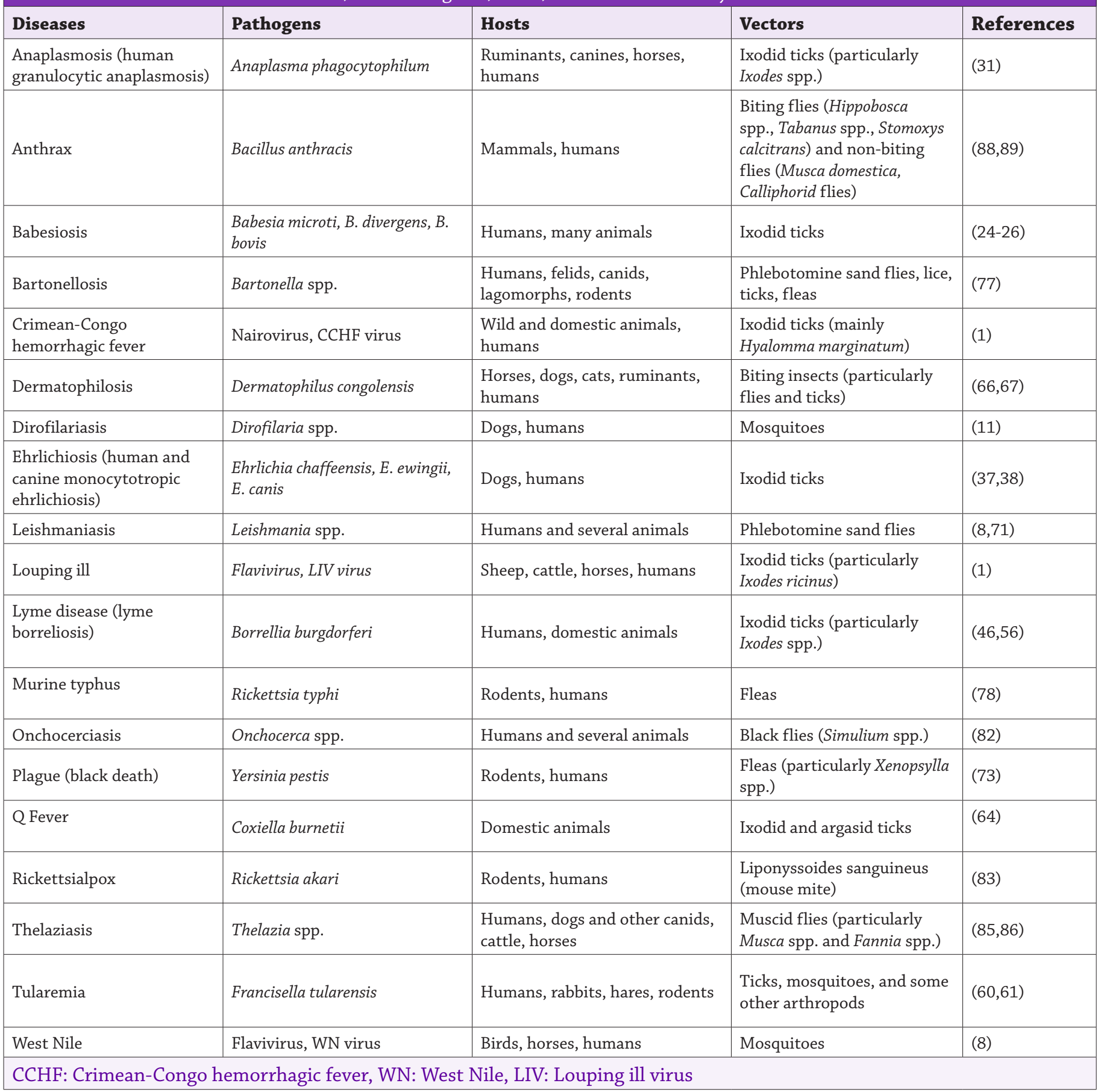

Flavivirus and family Flaviviridae) affecting mainly sheep but also cattle, horses, and humans. The main vector of LIV is Ixodes ricinus (43). The LIV was reported from different European countries, as well as from the northwestern part of Turkey (44). While there are no reports of human LIV infections in Turkey, an acute encephalomyelitis case was detected in sheep caused by the Louping ill/Russian Spring Summer virus complex. This virus was afterwards defined as Turkish sheep encephalitis virus and abbreviated as TTE80 strain. Thereafter, TTE80 strain was also described as a subgroup in tick-borne viruses of the family Flaviviridae by antigenic, pathogenic and molecular analyses (44). LB caused by Borrelia burgdorferi affects dogs and humans and is mainly transmitted by ticks in the Ixodes genus (45). Bor. burgdorferi was first identified in $I$. ricinus ticks collected from cattle in the Black Sea region in 1998 (46). In addition, a novel Borrelia sp. was isolated from Hyalomma aegyptium samples obtained from tortoises (47), and the spirochete was entitled as Bor. turcica sp. nov (48). A clinical lyme case was detected in a dog in 2007 (49), and anti-Bor. burgdorferi antibodies were also determined in dogs and horses (50). Few reports on LB cases in humans have been documented (51-54). However, the seropositivity rate was reported as $17 \%$ in people in Central Anatolia region (55), and $20 \%$ of patients $(n=50)$ reported symptoms compatible with $L B$ Erciyes University Hospital in the Kayseri province (56). In the 


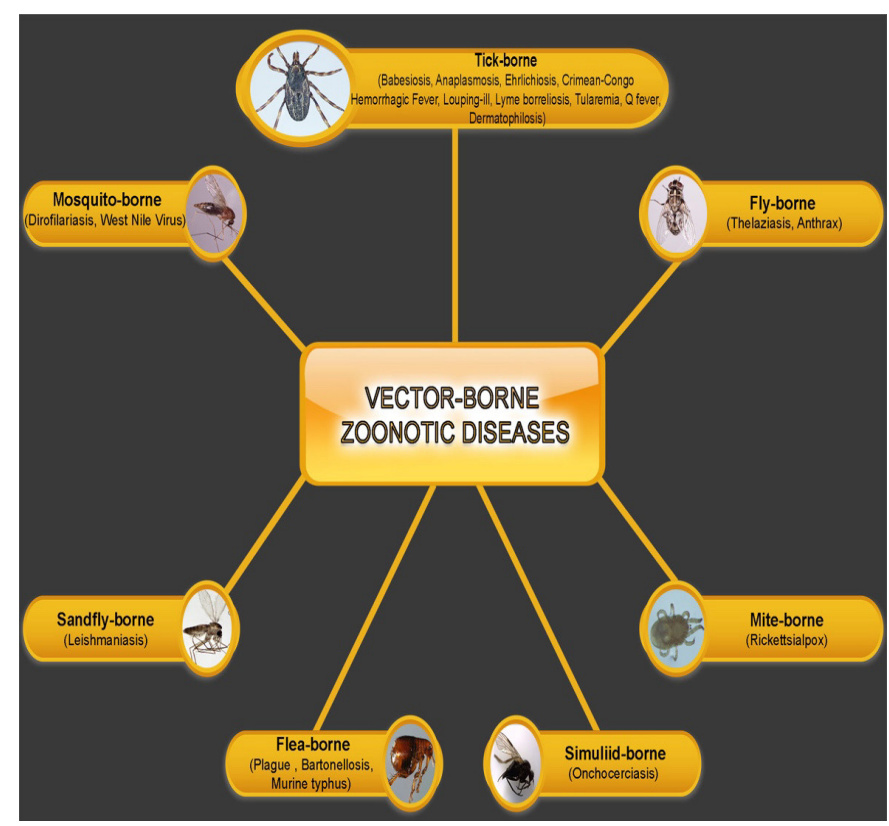

Figure 1. Vector-borne zoonotic diseases in Turkey

Marmara region, three LB cases have been confirmed serologically (54). Meanwhile, Bor. burgdorferi was also isolated from questing I. ricinus ticks sampled from parks and rural areas in the Thrace region of Turkey (57). In the same region, another similar field study was performed on ticks collected from tortoises and Rickettsia spp. and Bor. burgdorferi s.l. were molecularly detected (58). In addition, Bor. burgdorferi sensu stricto was found in unusual tick species, such as $H$. excavatum, $H$. marginatum and Haemaphysalis parva (59). Epidemiologically, these results reveal that Turkey has a high-risk potential for zoonotic LB.

Tularemia is caused by the gram-negative bacterium Francisella tularensis and ticks are the biological vectors of the agent. Tularemia is widespread in the northern hemisphere $(60,61)$ and is endemic in Turkey. The first tularemia epidemic in Turkey was recorded in 1936 in Thrace region followed by two outbreaks in 1945 and 1953 from Thrace and southern regions. A total of 507 cases were reported between 1988-2004. Tularemia was instated in the list of nationally notifiable diseases in 2005, and approximately 4824 cases have been recorded between 2005 and 2011. Despite the many human tularemia cases that have been reported, no F. tularensis was detected in ticks in a comprehensive study conducted in Kayseri region by molecular techniques $(60,61)$.

$\mathrm{Q}$ fever, which is endemic in Turkey, is an acute zoonotic infection caused by the obligate gram-negative bacterium Coxiella burnetii. Ixodid and argasid ticks can play a role as vectors (62). Some domestic animals (cows, sheep, goats, and dogs) have been reported as the reservoir of $C$. burnetii, and Ornithodorus lahorensis ticks are implicated in disease transmision in Turkey (2). However, human cases are relatively rare (63). A study on $C$. burnetti seropositivity in the Black Sea region in women with a history of abortion versus women with healthy births reported $15.6 \%$ and $11.1 \%$, respectively (64).

The skin disease Dermatophilosis, caused by the gram-positive actinomycete Dermatophilus congolensis, is transmitted by biting insects, particularly flies and ticks, via the mechanical transmission route (65). The disease affecting domestic and wild animals is of economic significance for wool production from sheep in many parts of the world. In Turkey, several cases of dermatophilosis in animals (66), and humans have been reported (67).

\section{Sandfly-borne Diseases}

Leishmaniasis is caused by parasitic Leishmania species that are transmitted by phlebotomine sandflies. Several animals and humans have been found as natural reservoir hosts of Leishmania species. The infection mostly occurs in three forms: visceral leishmanisis (VL), cutaneous (CL), and mucocutaneous leishmanisis. Although VL, also known as kalaazar, is fatal if remained untreated, CL causes skin lesion that can heal spontaneously (68). Zoonotic visceral leishmaniasis is endemic and caused by Leishmania infantum in the Aegean and Mediterranean regions of Turkey, usually observed in infants consistent with Mediterranean type. Leishmania isolates obtained from humans and dogs in various regions were described as L. infantum MON-1 and MON-98 with multilocus enzyme electrophoresis assay (8). Leishmania tropica and L. infantum are the responsible etiological agents for CL leishmaniasis (CL) in Turkey, especially prevalent in southeastern, eastern regions (8). Recently, L. major and L. donovani were also identified as causative agents of $C L$ in different regions (69). According to the official Ministry of Health records, 46,003 CL cases were reported between 1990 and 2010. Among those cases, 96\% of them were reported from Sanliurfa, Adana, Osmaniye, Hatay, Diyarbakir, Icel and Kahramanmaras provinces. The recent migrations from Syria where the disease is highly prevalent increased the relevance of CL as a public health threat in Turkey (8). In a study performed to demonstrate the effects of Syrian civil war on the epidemiology of $\mathrm{CL}$ in the Gaziantep province in southeast part of Turkey, a total of 567 people were hospitalized with the suspicion of $C L$, and 263 (46.4\%) were found positive by parasitological examination (70). Overall, 174 (66.1\%), 88 (33.5\%), and 1 (0.4\%) of the positive patients belonged to Turkish, Syrians, and Afghan ethnicity, respectively. Leishmania tropica was determined as the etiological agent in most of the cases, while only a few cases were caused by L. infantum (70). Canine Leishmaniasis (CanL) in dogs and wild canids is another serious form of the infection and has veterinary importance. The most common form of CanL is viscerocutaneous leishmaniasis caused by L. infantum. CanL is especially prevalent in Mediterranean and Aegean regions of Turkey. After 1993, the epidemiological studies were carried out in 22 different provinces and the prevalence ratios were found between $1.45 \%$ and $27.5 \%$. The overall prevalence of CanL was detected as $11.32 \%$ in Turkey (71).

\section{Flea-borne Diseases}

Plague (Black Death) is a fatal VBZD of rodents and humans caused by the gram-negative bacterium, Yersinia pestis and transmitted by infected fleas. The disease was the deadliest epidemic infection in the human history with very high mortality. From 2010 to 2015, there were 3,248 cases reported worldwide, including 584 deaths according to the World Health Organization (WHO) (72). In Turkey, the last reported cases included 32 patients from Akcakale, a town located on the Turkish-Syrian border, in 1947 (73).

Bartonellosis is caused by gramnegative bacteria, Bartonella species transmitted by various arthropod vectors, including 
sand flies, lice, ticks, and fleas. Natural hosts are humans, felids, canids, lagomorphs, and rodents. Humans are the only known reservoir hosts for $B$. bacilliformis and Bar. quintana. Cat scratch disease caused by Bar. henselae is transmitted by bites or scratches of infected cats to human (74). In Turkey, Bar. henselae seropositivities were reported as $7.9-41 \%$ in cats (75) and $6-22 \%$ in humans (76) while seropositivity for Bar. vinsonii subsp. berkhoffii was $6.6 \%$ in dogs (77).

Murine typhus (endemic typhus) caused by Rickettsia typhi (previously known as R. mooseri) is mainly transmitted by fleas from rodents to people. Most of the cases have been recorded from Southeast Asia, the Mediterranean region, and the United States with only two clinical murine typhus cases reported in Istanbul to date (78).

\section{Simuliid-borne Diseases}

Onchocerciasis is caused by the filarial worms Onchocerca spp. and transmitted by Simulium flies. Globally, there are at least 120 million people at risk for onchocerciasis caused by $O$. volvulus worldwide, of which $96 \%$ live in Africa. According to the WHO, 6.5 million people who have the disease suffer from dermatologic manifestations and 270,000 are blind (79). In Turkey, the first human case with O. caecutienus was reported in 1976 (80). In addition, an ocular human onchocercosis with $O$. lupi was reported by molecular analyses from Edirne region (81). The prevalence of bovine onchocercosis with 0 . armillata is $86 \%$ (82). In the past decade, a simuliid outbreak occurred in Central Kizilirmak Basin and the potential risk of onchocerciasis was revealed with a detailed molecular analyze of vector Simuliid flies in Kayseri region (8)

\section{Mite-borne Diseases}

Rickettsialpox is caused by Rickettsia akari transmitted by the mouse mite Liponyssoides sanguineus from rodents to humans. Rickettsialpox was firstly described in New York City in USA and then reported from Europe, Asia, Africa, and South America. Currently, rickettsialpox is not a notifiable disease. A clinical human rickettsialpox case was identified in a 9-year-old boy in Nevsehir region in Turkey (83).

\section{Fly-borne Other Diseases}

Thelaziasis is a dipteran-borne disease caused by parasitic eyeworms of the genus Thelazia transmitted primarily by muscid flies in the genera Musca and Fannia. Thelazia callipaeda, T. californiensis and T. gulosa have been reported in humans, dogs and cats. However, T. rhodesii infecting cattle is the most pathogenic species (84). In Turkey, bovine thelaziasis with T. rhodesii was reported as $5.5-22.0 \%$ in cattle $(8,85)$ and $1.2 \%$ in buffalo $(86)$.

Anthrax is an ancient and zoonotic infection in humans and animals caused by gram-positive bacteria, Bacillus anthracis. Biting flies (Hippobosca spp., Tabanus spp., Stomoxys calcitrans) and nonbiting flies (Musca domestica, Calliphorid flies) were demonstrated experimentally to transmit anthrax by several researchers (87). In Turkey, 464 animal cases were reported from Eastern part of the country between 1992 and 2004 (88). A total of 26,954 human anthrax cases were recorded by the Turkish Ministry of Health between 1960-2005, of which 6,861 were reported between 1990 and 2005 (89). Although the incidence of human anthrax is decreasing in Turkey, regional outbreaks are still reported with the great majority of cases being of the CL form (90). Recently, an animal anthrax case was reported from two pumas which died at the zoo in Kayseri province of Turkey in 2017 (2).

\section{CONCLUSION}

In this review, we summarized the present state of knowledge on VBZDs in Turkey. To date, 107 zoonotic bacterial, viral, parasitic and fungal diseases have been identified as rising threats for public health in Turkey, and almost one-fifth of these diseases are transmitted by arthropod vectors. Turkey is considered to be of medium-risk for climate change effects, but weather and climate-related extreme events have already been increasing in many regions in Turkey. These extreme conditions constitute new ecological habitats for vectors, with significance for epidemiological implications for distribution of VBZDs. Recent examples of VBZDs, such as leishmaniasis, Crimean-Congo haemorrhagic fever and West Nile, have been observed in regions of the country where these diseases were previously undetected. Currently, climate change is one of the priorities in sustainable development goals for Turkey as a member of the sixth global environment outlook assessment for the Pan-European region (91). In Turkey, a national program for mitigating the negative impacts of climate change on health have been prepared to protect the people from the adverse health effects to be caused by climate change in Turkey by Ministry of Health (92).

For controlling VBDZs and reducing the risks for emergence, a broad multidisciplinary network that includes the target public, clinicians, veterinarians and public health officials is essential following the One Health approach. This network can enhance awareness of the risk factors among all parties and oversee the implementation of the most appropriate strategies to manage and prevent vector-borne zoonotic infections. In accordance with the One Health concept, the development of advanced research projects for controlling VBZDs by expert researchers from all related scientific disciplines should also be a top priority. In addition, international cooperation and regional collaborations are very important for the prevention and control of the VBZDs and should be encouraged. We recommend that all responsible persons should carry out routine surveys not only in the endemic regions, but also in vector and pathogen free areas to determine the potential risk of the emergence of vectors and associated pathogens through human and animal mobility. Furthermore, we also suggest that a regional program utilizing the One Health Concept that considers an inter-disciplinary approach could be imperative to combat zoonotic infections as well as newly emerged fatal coronavirus pandemic, especially across country borders. In this regard, Turkey could provide leadership to bring together the necessary agencies and appropriate researchers under the auspices of international organizations to help shape a global policy for VBZD control in the middle-east region.

Recently, an administrative and political decision was taken, and “Turkey Zoonotic Diseases National Committee" was established by Ministry of Health in Turkey in 2019. This committee is tasked to prepare "Turkey Zoonotic Diseases Action Plan 2019-2023". Among the future objectives of this action plan are to raise public awareness about zoonotic diseases and prevention, to conduct risk analysis and to detect the threats, to develop and ensure the effectiveness of zoonotic disease diagnosis laboratories throughout the country, and to keep the treatment of diseases updated. 


\section{* Ethics}

Peer-review: Internally peer-reviewed.

\section{* Authorship Contributions}

Concept: Ö.D., A.İ., Design: Ö.D., A.İ., A.Y., M.D., Y.Ö., S.A., Data Collection or Processing: Ö.D., A.İ., A.Y., Analysis or Interpretation: Ö.D., A.İ., A.Y., M.D., Y.Ö., S.A., Literature Search: Ö.D., A.İ., A.Y., M.D., Y.Ö., S.A., Writing: Ö.D., A.İ., S.A.

Conflict of Interest: No conflict of interest was declared by the authors.

Financial Disclosure: The authors declared that this study has received no financial support.

\section{REFERENCES}

1. Inci A, Yildirim A, Duzlu O, Doganay M, Aksoy S. Tick-borne diseases in Turkey: A review based on One Health perspective. PLoS Negl Trop Dis 2016; 10: e0005021.

2. Inci A, Doganay M, Ozdarendeli A, Duzlu O, Yildirim A. Overview of zoonotic diseases in Turkey: The One Health concept and future threats. Turkiye Parazitol Derg 2018; 42: 39-80.

3. Jones KE, Patel NG, Levy MA, Storeygard A, Balk D, Gittleman JL, et al. Global trends in emerging infectious diseases. Nature 2008; 451: 990-3.

4. Kilpatrick AM, Randolph SE. Drivers, dynamics, and control of emerging vector-borne zoonotic diseases. Lancet 2012; 380: 1946-55.

5. Layton DS, Choudhary A, Bean AGD. Breaking the chain of zoonoses through biosecurity in livestock. Vaccine 2017; 35: 5967-73.

6. Mills JN, Gage KL, Khan AS. Potential influence of climate change on vector-borne and zoonotic diseases: A review and proposed research plan. Environ Health Perspect 2010; 118: 1507-14.

7. Caminade $C$, McIntyre KM, Jones AE. Impact of recent and future climate change on vector-borne diseases. Ann N Y Acad Sci 2019; 1436: 157-73.

8. Inci A, Yazar S, Tuncbilek A, Canhilal R, Doganay M, Aydin L, et al. Vectors and vector-borne diseases in Turkey. Ankara Univ Vet Fak Derg 2013; 60: 281-96.

9. Biskin Z, Duzlu O, Yildirim A, Inci A. The molecular diagnosis of Dirofilaria immitis in vector mosquitoes in Felahiye district of Kayseri. Turkiye Parazitol Derg 2010; 34, 200-5

10. Icen H, Sekin S, Simsek A, Kochan A, Celik OY, Altas MG. Prevalence of Dirofilaria immitis, Ehrlichia canis, Borrelia burgdorferi infection in dogs from Diyarbakir in Turkey. Asian J Anim Vet Adv 2011; 6: 371-8.

11. Yildirim A, Ica A, Atalay O, Duzlu O, Inci A. Prevalence and epidemiological aspects of Dirofilaria immitis in dogs from Kayseri province, Turkey. Res Vet Sci 2007; 82: 358-63.

12. Yildirim A, Inci A, Duzlu O, Biskin Z, Ica A, Sahin I. Aedes vexans and Culex pipiens as the potential vectors of Dirofilaria immitis in central Turkey. Vet Parasitol 2011; 178: 143-7.

13. Beden U, Hokelek M, Acici M, Umur S, Gungor I, Sullu Y. A case of orbital dirofilariasis in Northern Turkey. Ophthal Plast Reconstr Surg 2007; 23: 329-31.

14. Gungel H, Kara N, Pinarci EY, Albayrak S, Baylancicek DO, Uysal HK. An uncommon case with intravitreal worm. Intravitreal Dirofilaria infection. Br J Ophthalmol 2009; 93, 573-4.

15. Soylu M, Ozcan K, Yalaz M, Varinli S, Slem G. Dirofilariasis: An uncommon parasitosis of the eye. Br J Ophthalmol 1993; 77: 602-3.

16. Kucukaydin M, Sahin I. The third case of dirofilariasis conjunctivae in Turkey. Mikrobiyol Bul 1986; 20: 25-8.

17. Latifoglu O, Ozmen S, Sezer C, Yavuzer R, Altintas K, Uluoglu O. Dirofilaria repens presenting as apremasseteric nodule. Oral Surg Oral Med Oral Pathol Oral Radiol Endod 2002; 94: 217-20.
18. Hernandez-Triana LM, Jeffries CL, Mansfield KL, Carnell G, Fooks AR, Johnson N. Emergence of West Nile virus lineage 2 in Europe: A review on the introduction and spread of a mosquito-borne disease. Front Public Health 2014; 2: 271.

19. Kalaycioglu H, Korukluoglu G, Ozkul A, Oncul O, Tosun S, Karabay O, et al. Emergence of West Nile virus infections in humans in Turkey, 2010 to 2011. Euro Surveill 2012; 17: 20182.

20. Ozer N, Ergunay K, Simsek F, Kaynas S, Alten B, Caglar SS, et al. West Nile virus studies in the Sanliurfa province of Turkey. J Vector Ecol 2007; 32: 202-6.

21. Ozkul A, Yildirim Y, Pinar D, Akcali AA, Yilmaz V, Colak D. Serological evidence of West Nile Virus (WNV) in mammalian species in Turkey. Epidemiol Infect 2006; 134: 826-9.

22. Uyar Y, Bakir E. West Nile Virus (WNV) and current status of West Nile Virus in Turkey. Turk Hij Den Biyol Derg 2016; 73: 279-92.

23. Ozkul A, Ergunay K, Koysuren A, Alkan F, Arsava EM, Tezcan S, et al. Concurrent occurrence of human and equine West Nile Virus infection in Central Anatolia, Turkey: The first evidence for circulation of lineage 1 viruses. Int J Infect Dis 2013; 17: e546-51.

24. Poyraz O, Gunes T. Seroprevalance of Babesia microti in humans living in rural areas of the Sinop region. Turkiye Parazitol Derg 2010; 34: 81-5.

25. Gun H, Tanyuksel M, Yukari BA, Cakmak A, Karaer Z. First serodiagnosis of human babesiosis in Turkey. Turkiye Parazitol Derg 1996; 20: 1-7.

26. Kaya M. Investigation of frequency of babesiosis among human who have tick bite history living in Tatvan region. Master thesis, Erciyes University, Graduate School of Health Sciences, Department of Parasitology, Kayseri, 2011.

27. Gokce HI, Genc O, Akca A, Vatansever Z, Unver A, Erdogan HM. Molecular and serological evidence of Anaplasma phagocytophilum infection of farm animals in the Black sea region of Turkey. Acta Vet Hung 2008; 56: 28192.

28. Gunes T, Poyraz O, Atas M, Turgut NH. The seroprevalence of Anaplasma phagocytophilum in humans from two different climatic regions of Turkey and its co-seroprevalence rate with Borrelia burgdorferi. Turk J Med Sci 2011; 41: 903-8.

29. Aktas M, Vatansever Z, Altay K, Aydin MF, Dumanli N. Molecular evidence for Anaplasma phagocytophilum in Ixodes ricinus from Turkey. Trans R Soc Trop Med Hyg 2010; 104: 10-5.

30. Aktas M, Altay K, Dumanli N. Molecular detection and identification of Anaplasma and Ehrlichia species in cattle from Turkey. Ticks Tick Borne Dis 2011; 2: 62-5.

31. Ozlem MB, Karaer Z, Turgut K, Eren H, Irmak K, Inci A. Efficacy of longacting oxytetracycline on bovine anaplasmosis. Ankara UnivVet Fak Derg 1988; 35: $1-5$

32. Birdane FM, Sevinc F, Derinbay O. Anaplasma marginale infections in dairy cattle: Clinical disease withhigh seroprevalence. Bull Vet Inst Pulawy 2006; 50: 467-70.

33. Ulutas B, Bayramli G, Karagenc T. First case of Anaplasma (Ehrlichia) platys infection in a dog in Turkey. Turk J Vet Animal Sci 2007; 31: 279-82.

34. Dahlgren FS, Heitman KN, Behravesh CB. Undetermined human ehrlichiosis and anaplasmosis in the United States, 2008-2012: A catchall for passive surveillance. Am J Trop Med Hyg 2016; 94: 299-301.

35. Sari B, Taskin Tasci G, Kilic Y. Seroprevalence of Dirofilaria immitis, Ehrlichia canis and Borrelia burgdorferi in dogs in Igdir province, Turkey. Kafkas Univ Vet Fak Derg 2013; 19: 735-9.

36. Aysul N, Ural K, Cetinkaya H, Kuskucu M, Goktug T, Hasan E, et al. Doxycycline-chloroquine combination for the treatment of canine monocytic ehrlichiosis. Acta Sci Vet 2012; 40: 1031.

37. Duzlu O, Inci A, Yildirim A, Onder Z, Ciloglu A. The investigation of some tick-borne protozoon and rickettsial infections in dogs by Real Time PCR and the molecular characterizations of the detected isolates. Ankara Univ Vet Fak Derg 2014; 61: 275-82.

38. Unver A, Rikihisa Y, Borku K, Ozkanlar Y, Hanedan B. Molecular detection and characterization of Ehrlichia canis from dogs in Turkey. Berl Munch Tierarztl Wochenschr 2005; 118: 300-4. 
39. Leblebicioglu H, Ozaras R, Fletcher TE, Beeching NJ, ESCMID Study Group for Infections in Travellers and Migrants (ESGITM). CrimeanCongo hemorrhagic fever in travellers: A systematic review. Travel Med Infect Dis 2016; 14: 73-80.

40. Ergonul O. Crimean-Congo hemorrhagic fever. Lancet Infect Dis 2006; 6: 203-14.

41. Gunes T, Poyraz O, Vatansever Z. Crimean-Congo hemorrhagic fever virus in ticks collected fromhumans, livestock, and picnic sites in the hyper endemic region of Turkey. Vector Borne Zoonotic Dis 2011; 11: 1411-6.

42. Inci A, Yildirim A, Duzlu O. The current status of ticks in Turkey: A 100year period review from 1916 to 2016. Turkiye Parazitol Derg 2016; 40: 152-7.

43. Gilbert L. Louping ill virus in the UK: A review of the hosts, transmission and ecological consequences of control. Exp Appl Acarol 2016; 68: 363-74.

44. Hardly WJ, Martin WB, Hakioğlu F, Chifney STE. A viral encephalitis of sheep in Turkey. Pendik Institute J 1969; 1: 89-100.

45. Ross Russell AL, Dryden MS, Pinto AA, Lovett JK. Lyme disease: Diagnosis and management. Pract Neurol 2018; 18: 455-64.

46. Polat E, Calisir B, Yucel A, Tuzer E. The two first Borrelia strain isolated and growth form Ixodes ricinus in Turkey. Turkiye Parazitol Derg 1998; 22: 167-73.

47. Guner ES, Hashimoto N, Kadosaka T, Imai Y, Masuzawa T. A novel, fastgrowing Borrelia sp. isolated from the hard tick Hyalomma aegyptium in Turkey. Microbiol 2003; 149: 2539-44.

48. Guner ES, Watanabe M, Hashimoto N, Kadosaka T, Kawamura Y, Ezaki $\mathrm{T}$, et al. Borrelia turcica sp. nov., isolated from the hard tick Hyalomma aegyptium in Turkey. Int J Syst Evol Microbiol 2004; 54: 1649-52.

49. Gulanber EG, Gulanber A, Albayrak R. Lyme disease (Borreliosis) in a Saint Bernard dog: First clinical case in Turkey. J Vet Anim Sci 2007; 31: 367-9.

50. Bhide M, Yilmaz Z, Golcu E, Torun S, Mikula I. Seroprevalence of antiBorrelia burgdorferi antibodies in dogs and horses in Turkey. Ann Agric Environ Med 2008; 15: 85-90.

51. Bulut C, Tufan ZK, Altun S, Altinel E, Kinikli S, Demiroz AP. An overlooked disease of tick bites: Lyme disease. Mikrobiyol Bul 2009; 43: 487-92.

52. Eroglu C, Esen S, Hokelek M. A case of lyme meningitis characterized with meningitis and encephalitis findings. Infeks Derg 2002; 16: 225-8.

53. Koc F, Bozdemir H, Pekoz T, Aksu HS, Ozcan S, Kurdak H. Lyme disease presenting as subacute transverse myelitis. Acta Neurol Belg 2009; 109: 326-9.

54. Polat E, Turhan V, Aslan M, Musellim B, Onem Y, Ertugrul B. First report of three culture confirmed human Lyme cases in Turkey. Mikrobiyol Bul 2010; 44: 133-9.

55. Demirci M, Yorgancigil B, Tahan V, Arda M. The lyme disease seropositivity in Isparta province in those with a history of tick-bite. Infeks Derg 2001; 15: 17-20.

56. Utas S, Kardas Y, Doganay M. The evaluation of Lyme serology in patients with symptoms which may be related with Borrelia burgdorferi. Mikrobiol Bul 1994; 28: 106-12.

57. Sen E, Uchishima Y, Okamoto Y, Fukui T, Masuzawa T, Kadosaka T, et al. Molecular detection of Anaplasma phagocytophilum and Borrelia burgdorferi in Ixodes ricinus ticks from Istanbul metropolitan area and rural Trakya (Thrace) region of north-western Turkey. Ticks Tick-Borne Dis 2011; 2: 94-8.

58. Kar S, Yllmazer N, Midilli K, Ergin S, Alp H, Gargili A, et al. Presence of the zoonotic Borrelia burgdorferi sl. and Rickettsia spp. in the ticks from wild tortoises and hedgehogs. MUSBED 2011; 1: 166-70.

59. Orkun O, Karaer Z, Cakmak A, Nalbantoglu S. Spotted fever group rickettsiae in ticks in Turkey. Ticks Tick-Borne Dis 2014; 5: 213-8.

60. Duzlu O, Yildirim A, Inci A, Gumussoy KS, Ciloglu A, Onder Z. Molecular investigation of Francisella-like endosymbiont in ticks and Francisella tularensis in ixodid ticks and mosquitoes in Turkey. Vector-Borne Zoonotic Dis 2016; 16: 26-32.
61. Ulu-Kilic A, Doganay M. An overview: Tularemia and travel medicine. Travel Med Infect Dis 2014; 12 (6 Pt A): 609-16.

62. Njeru J, Henning K, Pletz MW, Heller R, Neubauer H. Q fever is an old and neglected zoonotic disease in Kenya: A systematic review. BMC Public Health 2016; 16: 297.

63. Payzin S. Epidemiological investigations on Q fever in Turkey. Bull World Health Organ 1953; 9: 553-8.

64. Gunal O, Demirturk F, Barut S, Kilic S, Erkorkmaz U, Aytekin FY, et al. A preliminary report of relationship between abortion and $\mathrm{Q}$ fever in Central Black Sea region Turkish woman. Cumhuriyet Med J 2014; 36 : $337-43$.

65. Inci A, Yildirim A, Duzlu O. Dermatophilosis (streptothrichosis). In: Medical and veterinary importance of ticks. Ed. Inci A. Erciyes University Press, Kayseri, Turkey. 2016.p.117.

66. Oruc E, Aktas MS, Aydin H. Dermatophilosis in a simmental calf. Lucrari Stiintifice-Medicina Veterinara Universitatea de StiinteAgricole si Medicina Veterinara "Ion Ionescu de la Brad" Iasi 2014; 57: 283-7.

67. Harman M, Sekin S, Akdeniz S. Human dermatophilosis mimicking ringworm. Br J Dermatol 2001; 145: 170-1.

68. Burza S, Croft SL, Boelaert M. Leishmaniasis. Lancet 2018; 392: 951-70.

69. Özbilgin A, Töz S, Harman M, Günaştı Topal S, Uzun S, Okudan F, et al. The current clinical and geographical situation of cutaneous leishmaniasis based on species identification in Turkey. Acta Trop 2019; 190: 59-67.

70. Ozkeklikci A, Karakus M, Ozbel Y, Toz S. The new situation of cutaneous leishmaniasis after Syrian civil war in Gaziantep city, Southeastern region of Turkey. Acta Trop 2017; 166: 35-8.

71. Ozbel Y. The infections transmitted by sand flies in Turkey. Ankara Üniversitesi Veteriner Fakültesi Dergisi 2013; 60: 225-8.

72. Grácio AJDS, Grácio MAA. Plague: A millenary infectious disease reemerging in the XXI century. Biomed Res Int 2017; 2017: 5696542.

73. Doganay M, Demiraslan H. Refugees of the Syrian civil war: Impact on reemerging infections, health services, and biosecurity in Turkey. Health Secur 2016; 14: 220-5.

74. Álvarez-Fernández A, Breitschwerdt EB, Solano-Gallego L. Bartonella infections in cats and dogs including zoonotic aspects. Parasit Vectors 2018; 11: 624.

75. Celebi B, Kilic S, Aydin N, Tarhan G, Carhan A, Babur C. Investigation of Bartonella henselae in cats in Ankara, Turkey. Zoonoses Public Health 2009; 56: 169-75.

76. Yilmaz C, Ergin C, Kaleli I. Investigation of Bartonella henselae seroprevalence and related risk factors in blood donors admitted to Pamukkale University Blood Center. Mikrobiyol Bul 2009; 43: 391-401.

77. Celebi B, Taylan A, Kilic S, Akca A, Koenhemsi L, Pasa S, et al. Seroprevalence of Bartonella vinsonii subsp berkhoffii in urban and rural dogs in Turkey. J Vet Med Sci 2010; 72: 1491-4.

78. Serefettin O. Murine typhus at Istanbul. Bull Soc Pathol Exot 1934; 27: 831-3.

79. Grácio AJ, Richter J, Komnenou AT, Grácio MA. Onchocerciasis caused by Onchocerca lupi: An emerging zoonotic infection. Systematic review. Parasitol Res 2015; 114: 2401-13.

80. Yuce G, Girgin H. An onchocerciasis case. Turk Vet Hek Dern Derg 1967; 37: 18-21.

81. Sakru N, Testini G, Gurlu VP, Yakar K, Lia RP, Dantas-Tores F, et al. Case report: First evidence of human zoonotic infection by Onchocerca lupi (Spirurida, Onchocercidae). Am J Trop Ed Hyg 2012; 8: 55-8.

82. Alibasoglu M, Goksu K, Erturk E, Guler S. Onchocercosis cases in cattle in Turkey (Onchocerca armillata Railliet ve Henry, 1909). Ankara Univ Vet Fak Derg 1969; 16: 50-60.

83. Ozturk MK, Gunes T, Kose M, Coker, Radulovic S. Rickettsial pox in Turkey. Emerg Infect Dis 2003; 9: 1498-9. 
84. Otranto D, Eberhard ML. Zoonotic helminths affecting the human eye. Parasit Vectors 2011; 4: 41.

85. Tasci S, Toparlak M, Yilmaz H. The prevalence of Theleazia species in catlle slaughtered at Van abottoir. Ankara Univ Vet Fak Derg 1989; 36, 352-7.

86. Guralp N, Oguz T. Thelaziose in water buffalos (Bubalus bubalis) in Turkey. Ankara Univ Vet Fak Derg 1970; 17: 109-13.

87. Goel AK. Anthrax: A disease of biowarfare and public health importance. World J Clin Cases 2015; 3: 20-33.

88. Ozkurt Z, Parlak M, Tastan R, Dinler U, Saglam YS, Ozyurek SF. Anthrax in eastern Turkey, 1992-2004. Emerg Infect Dis 2005; 11: 1939-41.

89. Doganay M, Metan G. Human anthrax in Turkey from 1990 to 2007. Vector Borne Zoonotic Dis 2009; 9: 131-40.
90. Demiraslan H, Borlu A, Sahin S, Buyuk F, Karadag Y, Doganay M, et al. The epidemiological investigation and control of an anthrax outbreak in a village in Central Anatolia, Turkey. Pathog Glob Health 2017; 111: 20611.

91. Regional Context and Priorities. (cited 17 October 2019). In: Global environment outlook GEO-6 assessment for the Pan-European region. Available from: http://uneplive.unep.org/media/docs/assessments/ GEO_6_Assessment_pan_European_region.pdf

92. Turkey's National Climate Change Adaptation Strategy and Action Plan. (cited 17 October 2019). Available from: http://www.dsi.gov.tr/docs/ iklim-degisikligi/turkeys-national-climate-change-adaptation-strategyand-action-plan.pdf?sfvrsn $=2$ 